\title{
海 外 報 告
}

\section{粉粒体の貯槽・輸送・ハンドリングに関する 国際会議出席報告}

\author{
辻裕* \\ Yutaka TSUJI
}

標記会議がオーストラリア, ニューサウスウェールズ 州, ニューカッスル大学に批いて1983年 8 月22〜24日の 3 日間行なわれた。これに参加の機会を得たので体験談 を交光会議の内容について報告する。オーストラリアの 会議に先立ち，青木教授（東大）率いる訪台視察団にも 加わったので, 前半は台潜, 後半はオーストラリアとい ら日程で丁度 2 週間, 日本を留守した。

\section{1. 会議開催前}

日本から台北へ向った時期はお盆の頃にかかったた め, 飛行機は満席であった。台湾大学での講演会の後, バンコック，ブリスベーン経由でシドニーに向ったが， こちらの方はまったくがら空きで， B747 の 4 人掛けの 席をた抗して充分な睡眠をとることができた。シドニー に一泊後, あくる日（8月21日）シドニーから列車でニ ニーカッスルに向った。ファーストクラスとエコノミク ラスの金額の差は 3 ドル（オーストラリア 1 ドル $\doteqdot 220$ 円）であるが，切符売場で聞けば，中はそら変らないと いわれたので, エュノミーに乗った。出発後, 予想して いた通りのどかな田園風景にうとうとしていると，斜め 後の席でヒッピーまがいの男女と乞食に近いなりをした 男とが口論をはじめ，やがて大声をはりあげるつかみあ いに発展した。他の乗客は皆知らんふりをしていたが， そのらち車掌が飛んできて治った。車空の風景とはちぐ はぐな光景にいきなり出くわしたが，この乱闘ショウの おかげで 3 時間余りの汽車の旅も意外に短く感じられ た。

会議の主催者が参加者のために準備したニューカッス ルのホテル (Travelodge) は我々日本人の基準でいえ ば素晴らしい場所に位置していた。このホテルは小さな 半島の尖端に近いところにあり, ホテルのすぐ前には白 い砂浜が広がり, 部屋に居ながらにして波の打ち寄せる

昭和59年 1 月 17 日受付

*大阪大学工学部産業機械工学科 (广565 吹田市山田丘 2-1)

TE L 06-877-5111
雄大な太平洋が見られる。外の気温は大体 $14 \sim 18^{\circ} \mathrm{C}$ 位 で割合快適であった。驚いたことに海岸には泳いだりサ ーフィンを楽しむ人々が結構いた。8月末とはいえこ こでは一応冬である。自分自身も少々運動不足を感じて いたので用意していたトレーニングウェアと運動靴には きかえ, 町の偵察を兼ね早速, 海岸から町中へとジョギ ングにおよんだ。ニューカッスルは工業地带として知ら れ，事実，ホテルのある場所から工場群が遠望できる が，そのよらな地帯のすぐ近くに㮃いの海岸やリゾート ・ホテルがある点にこの国の持つゆとりが感じられた。 タ方, ホテルのレストランで一人寂しく食事をしてい るところへ, 3 年前の粉体の京都シンポジゥムに参加し た Dr. A. Reed (英, Thames Polytechmic) と Dr. P. Arnold (豪, Wollongong Univ.) がともに奥さ ん連れでやってきた。聞けば Reed は会議に先立ち Wollongong 大学の空気輸送実験装置を見学してきたと のことであった。早速, 彼らに合流した。そのうち京都 シンポジゥムの話に花が咲いた。今回の会議では, その 委員長でもある Prof. Roberts(蒙, New Castle Univ.) や Prof. Rademacher (オランダ, Twenty Univ.) の ように京都シンポジゥムに出席した人々に会ったが, 誰 もがシンポジゥムやその後の東京フォーラムが素晴らし かったといってくれた。始めは外交辞礼かとも思った が，よく考えてみると挫座成りの国際会議が增える昨 今, 京都シンポジゥムが正しく評価されていると見てよ いであろう。当時私はまったく役立たずであったが,シ ンポジウムに骨を折られた諸先生方のおかげで，ある意 味では大きな顔ができた。そうこうする内，Dr. Wöhlbier 夫妻（西独, Trans. Tech.) があらわれた。彼は 1981年に創刊された Int. Journal of Bulk Solid Handling の編集長発行人をしており,目下,猛烈にこの新しい 雑誌の売り込みを行なっているところである。 Roberts 教授もこの雑誌の編集委員の一人である関係もあって, 会議の登録場では雑誌の内容見本を展示し Wöhlbier は 奥さんと共に熱心に説明にまわっていた。彼の雑誌社は 
西独の Claustha1 Zellerfeld に本拠を持ち,私も以前ゲ ッチンゲンに居た頃, ハルッ山のふもとの町 Clausthal ヘドライブに出かけたり，スキーを楽しんだこともあっ たので，当時の思い出を語っているうち，それまでまっ たく面識がなかったが，すっかり親しくなった。1983年 秋に出版する極東の特集号のゲラ刷りを見せ, Wöhlbier はオーストラリアの会議のあと日本を訪問するという。 それでは日本に来た時には扮世話しましょうということ になった。後日談になるが, 京都では井伊谷教授, 東京 では青木教授汇彼を紹介し, 日本における彼のビジネス の役には立ったと思っている。

\section{2. 会議について}

登録場で手渡たされた名簿によれば，参加者数は 210 名余りであり, 実祭に見た感じでもその程度の人々が常 時集っていた。プロシーディングスに収録された論文数 は66編，海外からのものは17編であった。日本からは 陳・富田（九工大, 敬称略), と我々の論文が出された。 実際に出席したのは私のみにとどまったことからもわか るように, 海外からの実際の参加者は収録された論文数 よりずっと減っていた。しかし一方では，まだ名簿に名 前が記載されていない人も参加していたので確かな数は つかみにくかった。

海外からの参加者にとって助かったのは, 論文集, 昼 食, パーティ，ポストコンファレンスッアーなどを含む 登録料がすべて無料であったことである。その上，プ ログラムには明記されていないが，最終日の夕方には Roberts 夫妻は我々外人を格式の高いニューカッスル。 クラブでのディナーに招待し，さらに翌日，海岸沿いの 1)ゾートからハンターバレー（ワインの産地として有 名)へのドライブにもさそった。拈さそいにはすべて応 ビたので滞在中，予想外に打金がかからなかった。後で Arnold に聞いたことであるが，会議参加に際し金銭的 な援助を希望する申し込みが外国から何件かあったが， そのような資金がなくすべて断ったそうである。しか し, 海外からの実際の参加者に対し， Roberts 教授は奥 さんと一緒にベストを尽してもてなしたという印象を強 く受けた。

会場は大ホールと呼ばれる全員がそろら場所の他, 3 ケ所設けられた。その 3 ケ所の会場は, 機械的ハンドリ ソグ, 輸送, 貯槽のように分類され，同時に進行したた め自分の専門である輸送のセッション以外には参加の機 会がなかった。そのかわり，毎日のはじめのセッション では夫々の専門領域の基調報告が大ホールで行なわれ， 全員が顔を合わせるように企画されていた。各セッショ

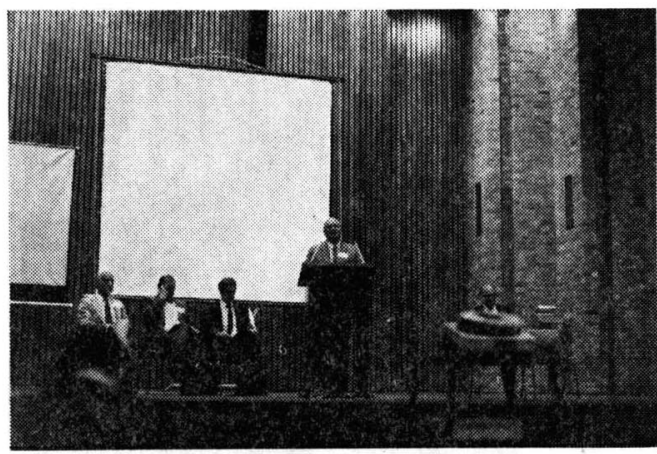

図1 開会のあいさつをする Prof. 'Roberts

ンの座長はすべて地元オーストラリアの人々が務め, 基 調報告を除く各講演には質問時間を含めすべて 30 分とら れた。

まず初日は Roberts 教授のあいさつのあと，2つ の歓迎の辞があり, つづいてオーストラリア石炭協会 (Austrelan Coal Associacticn) の Dr. J. B. Ritchie による「オーストラリアの石炭——その意味と挑戦」と 題する講演があった。Ritchie 氏はオーストラリアの貿 易収入の最大を担っているのは石炭であり，そのうちの 2/3 は日本に輸出されているというようなことから話を 始めた。石炭鉱業に直接從事する人々が 3 万人, 間接的 な場合を含めると 20 万人以上といら数字は，この国の人 口構成を考学るとかなりの数になるのであろう。氏は, 石炭が今後も輸出の No. 1 の座を維持することと本会議 で取り上げられているテーマの関連を力説した。この Ritchie 氏の講演の時, 地元のテレビ局が会議の撮影に きた。その日の夕方, 時間の合い間を妨って Dr. T. G. Callcott の自宅をたずねたが，そこで丁度このニュース を見ることができた。この会議では穀物なども扱われて いるが，石炭がらみのテーマが压倒的に多く，オースト ラリアの重要産業に深く関連する会議として, テレビの ニュースに取り上げられたのであろう。

自分の専門上, どらしても空気輸送の方に話題が傾い て恐縮であるが，講演としては南アフリカ, Witwatersrand 大学の Prof. R. D. Marcus の話 (Three Phases of Freight Pipeline Develonment) は肩がこ らず聞いていて楽しかった。彼とはこの種の国際集会で しばしば顔を合わせており，互いに顔なじみである。押 し出しが強いがどこが憎めない個性を持っている。彼は 相変らず空気輸送至上主義者で, 何が何でも空気輸送を と主張する点は, 同じ分野でメシを飯っている者として 見ていて実に愉快である。もしスラリ輸送至上主義者と はち合わせていたら，激しいケンカがはじまるにちがい 


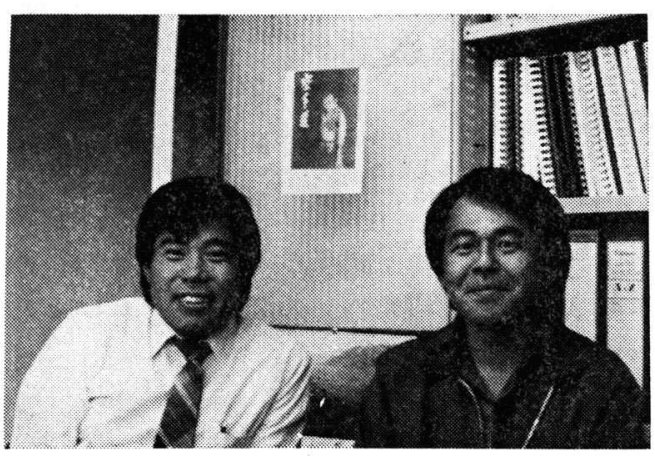

図 2 BHP で活躍する二人の日本人

左 : 吉永益久氏, 右 : 野村伸一郎氏

ない。今回, 彼は磁気浮上型のカプセル輸送や Reactor pipeline (反応を伴う輸送), The people pipeline (人 を輸送)など新奇な話題を提供していた。

私の発表は「高濃度空気輸送研究の日本の現状」と題 するもので, 2 日目午後行なった。会場には, この分野 では古参の Dr. R. A. Duckworth も顔を見せていた。 質疑の際, 前出の Reed が我々の高濃度輸送実験にお ける管内のプラグの発生数について具体的な数值を質問 してきた。それに対し適当に答えていると Thames Polytechnic での実験では何ら補助的な手段を用いずに 多数のプラグを発生するのに成功したと主張してきたの で，君の場合は偶然でラッキーなんだと切り返えした ら，会場内が少し涌いた。そうしたら彼は顔を赤らめか んかんになって反論してきた。ただし，ことわっておく が Reed は頭が切れ, 弁もたつ好青年で, 私の良き友 人の一人である。

\section{3. オーストラリアエ学会 (The Institution of Engineers, Australia)}

次に, この会議の主催団体であるオーストラリア工学 会について少し述べておこう。オーストラリアでは機峨 学会, 化学工学協会……のよりに学会が独立していな い。工学関係の学協会を全部あわせたような団体が,こ れと考えればよい。もちろん非営利団体である。2週間 に一度の割合で会誌を発行し, 各種の学会を主催してい る。論文集も各専門ごとに刊行している。会員数は約 37,000人である。オーストラリアの工学上または技術的 なことについて情報を得たい場合, 空口が 1 本であるの でここに連絡すればよい(と思われる)。

\section{4. 二人の日本人}

今回の会議参加の副産物以上の事柄として, 二人の日
本人に出会ったことも書きとどめておきたい。一人は野 村伸一郎氏で, 田中達夫教授（北大）のもとで粉じん爆 発で学位を取った後, ニューカッスルにある BHP*の 中央研究所ですでに 3 年以上研究活動を続けている人で ある。もともと，BHP で活躍した Dr. Callcott と共 同で研究をしていたが, Callcott さんが引退したあと, 現在, 微粉炭燃焼炉の炬内の解析を手がけている。BHP では理論計算を担当する貴重な存在と見受けたが，ひょ らひょらとした雲囲気の持ち主でマイペースで仕事をし ているよらであった。野村氏の下宿で， 1 年間かかって よらやく覚えたといらギターを聞かせてもらった。今， 釣りに夢中だそうで，さすがコスモポリタン田中教授の お弟子さんだけあって,オーストラリアの風土とテンポ にきっちりと溶けこんでいた。下宿の家貨が高いとぼや いていたが，すぐ近くのパブ（その名も Blackbut）が 気に入りすぎ，そのパブに通うために条件の悪い下宿 をがまんしているとのことであった。野村氏とはその Blackbut でワイングラスを傾け，多いに語り合った。 是非この報告記事で紹介したいもら一人は吉永益久氏 である。野村氏と同様, BHP の研究所に勤務している。 吉永氏には本誌 Vol. 21, No. 3(1984年 3 月号) に「二ュ 一カッスル市と IPTACCS プロジェクト」と題する記 事を寄せてもらったので, ご記憶の読者もおられるであ ろら。氏の許可を得ているのでプライベートなことまで 書かせてもららが, 吉永氏にはオーストラリア人の奥さ んと 3 人の子供さんがあり，も510数年間オーストラリ ア住いである。完全にこの地に根を扔ろしているといっ てよい。会議の開催中に42才の誕生日を迎えだ。氏の仕 事内容は1984年 3 月号の本誌に詳しいので省略するが, この人がまたかなりの豪傑で, BHP の研究所と隣り合 せにあるニニーカッスル大学で空手を教光, その一方で Roberts 教授の下で Ph.D のための研究も行なってい る。

この二人にはニューカッスル滞在中なにかと世話にな った。吉永氏と知りあったきっかけは，氏が BHP から 派遣されて会議に出席したからであり, 吉永氏の紹介で 野村氏と知り合い，その野村氏が Dr. Callcott の家へ 私を連れてゆき，Callcottに空気輸送を専門にしてい るといえば，それじゃどこそこの会社の空気輸送システ ムが最近完成したので是非見学に行きなさいとすすめら れ……とい風にいもずる式に私の行動が展開されてい った。野村氏の扔かげで BHP の中もゆっくり見学させ てもらえた。これには Arnoldや Reed も一緒であっ た。

* The Broken Hill Proprietary Company Limited 


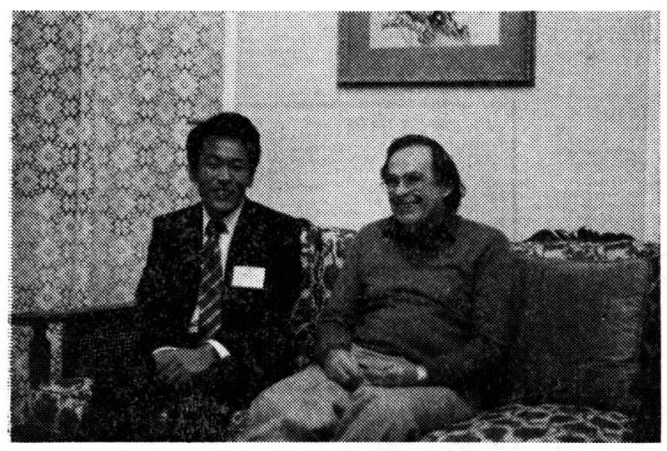

図 3 Dr. Callcott と

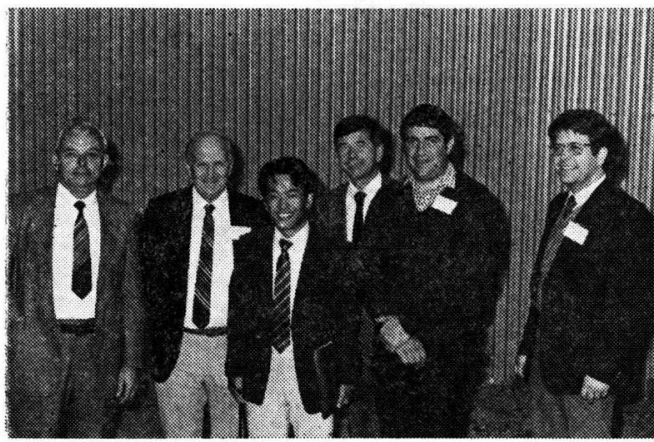

図4 Prof. Roberts の実験室にて

左から Prof. Rademacher, Prof. Roberts, 筆者, Dr. Wöhlbier. Prof. Marcus, Dr.Arnold

当初, 日本からの参加は一人であったので, じっくり
講演を聞く予定でのぞんだが，いろんなことが続々と起 こり，椅子の盜たまる間もなく気がついたら会議が終っ ていたといらのが寒である。

\section{5. 会議終了後}

先に述ベたハンターバレーへのドライブから直接 Arnold に連れられ Wollongong 大学の実験装置を見学 した。1983 年末からしばらく日本に滞在している Dr. A. G. McLean は Arnold と同じ機械工学科に所属し ている。彼らは長らく Roberts 教授とともに貯槽の研 究を行なってきたが，数年前から Arnold は空気輸送 の研究をはじめている。我々とは異なり，ほとんど企業 からの委託研究の形をとっているので, 輸送の装置その ものは我々が持つものよりも充実しており，外観ではや や差がつけられているなと感じた。

さて，しめくくりは帰りの空の旅であるが，往路に台 湾経由のタイ航空を利用したのがたたって，まさに空の 各駅停車となってしまった。シドニーを出てからシンガ ポールにとまり, 次いでパンコックで一泊させられ, 翌 日は香港, 台北とその都度 $1 \sim 2$ 時間程度, 待ち合い室 に入れられて丸二日かかってょうゃく大阪にたどりつい た。

最後に, 会議出席に際し粉体工学会「海外国際会議の 出席補助」の援助を受けたことを記し，ここに謝意を表 する。

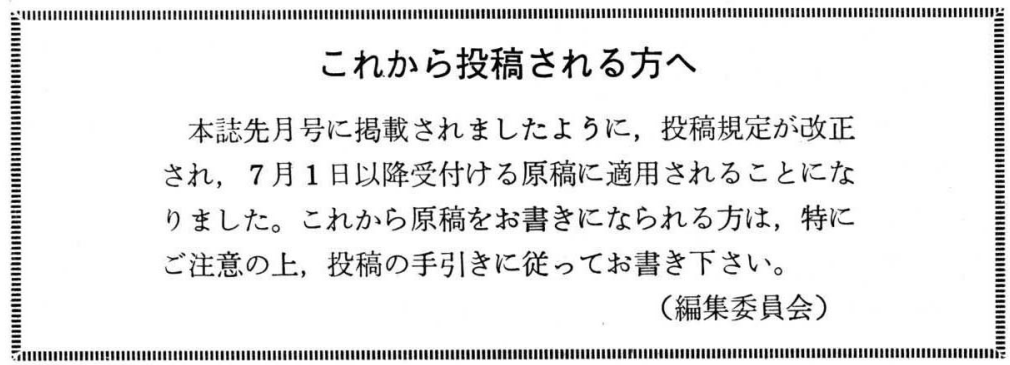

